\title{
the crypt, the haunted house, of cinema
}

ALAN CHOLODENKO

Last night I was in the Kingdom of Shadows.

If you only knew how strange it is to be there. It is a world without sound, without colour. Everything there- the earth, the trees, the people, the water and the air-is dipped in monotonous grey. Grey rays of the sun across the grey sky, grey eyes in gre y faces, and the leaves of the trees are ashen grey. It is not life but its shadow, it is not motion but its soundless spectre.

Here I shall try to explain myself, lest I be suspected of madness or indulgence in symbolism. I was at Aumont's and saw Lumière's cinématograph—moving photography.

Maxim Gorky, July $1896 .^{1}$

What there is on the screen is nothing but shadows. Something even more dead than words.

Orson Welles, $1971 .^{2}$

Cinema is the art of ghosts.

Jacques Derrida, 1983.3

Spooky, isn't it?!

As we know, it is a cliche that what we see on the screen is ghosts, phantoms, spectres. What I propose in this essay is that that cliché be taken seriously-do I dare say it, 'deadly' seriously-be given rigorous analytic attention for its relevance to the thinking of cinema and its senses, while at the same time acknowledging that even the finest account must come face to face with the 'fact' that there is no ghostbuster, not even the analyst/theorist of cinema, 
not even the Marxist analyst/theorist of cinema, so powerful as to master, defeat and eradicate the spectre of cinema. ${ }^{5}$ Indeed, this is what for me, after Raymond Bellour, cinema is never not telling us, its analysts. ${ }^{6}$ For Derrida, all analysis is enabled by the spectre, is itself a conjuring of the spectre. For him, the spectre is not of the order of ontology but of hauntology. He writes, 'Ontology opposes it [hauntology] only in a movement of exorcism. Ontology is a conjuration'. ${ }^{7}$ Ontology wishes to conjure away the spectre that enables, conjures, it. The hauntological makes every concept a concept of the spectre and a spectre of a concept. ${ }^{8}$ It is a key premise of this essay that not only is the spectre a privileged subject of film but that it would be the ur figure of cinema, if cinema could have an ur figure, if the spectre could be an ur figure, a figure not only operating at every second at every level in every aspect of every film but also at the level of the cinematic, or rather animatic, apparatus of film, hence at the level of film 'as such'.

But since for me there is no essence to film as there is no essence to the spectre, any ur figurewould, of necessity, call for its putting in quotation marks, under erasure (sous rature). The very figure of cinema, the figure of the figure(s) of cinema, would be this thing, this nothing, of which Derrida speculates: 'the figure of the ghost is not just one figure among others. It is perhaps the hidden figure of all figures'. ${ }^{9}$ This would mean that in cinema we find a privileged, exemplary instance of this 'figure of all figures'. ${ }^{10}$ Furthermore, insofar as for Derrida 'the spectrogenic process corresponds to a paradoxical incorporation' the cry ptic incorporation-the cinema is for me not only a privileged, exemplary instance of that process of the spectre but also at the same time a privileged, exemplary instance of cryptic incorporation. ${ }^{11}$ The crypt of cinema would be for me the artifactual, prosthetic 'body', that space of invisible visibility and visible invisibility, of the cinema 'itself' become not only the host for the spectres it images but itself a ghost, a second spectre, that spectre for which the spectator-subject and the world are the host, even as such hosting thereby makes spectres of them as it at the same time makes a host of the spectres of cinema.

But what, more precisely, is the cryptic incorporation? Tellingly, it is in a film, Ken McMullen's Ghost Dance, that Derrida offers a brief description of it. Tellingly, too, as part of his improvised commentary, he describeshimself as a phantom, even as his cameo role and his sudden surprising appearance (and reappearances) in the film possess for me a spectral character. He declares:

F reud. We were talking about the ghost of Freud just now. You know, ghosts don't come. They return (reviennent). As we say in French, they are revenants. That presupposes a memo ry of the past that was never under the form of presence. But I've been intrigued by a certain theory which some psychoanalyst friends, Nicolas Abraham, who is now dead, and Maria To rok, have developed from Freud. Their theory of ghosts is based in fact on a theory of 
mo u rning. In normal mourning, Freud says, one interiorizes the dead. One takes it into oneself, one assimilates it; and that interiorization is idealization. It accepts the dead. Whereas in mourning that doesn't develop normally, a work of mourning that goes wrong, there is no true interiorization. There is what Abraham and Torok call an incorporation. The dead is taken into us but doesn't become a part of us. It occupies a particular place in our body. It can speak on its own. It can haunt and ventriloquize our own proper body and our own proper speech. So that the ghost becomes enclosed in a crypt in us, a sort of graveyard for the ghost. A ghost can be also not only our proper unconscious but more precisely the unconscious of the other. It is the unconscious of the other which speaks in our place. It is not only our unconscious but the unconscious of the other that can play tricks on us which speaks in our place. It can be terrifying, it can be terrifying. But that's when things really start to happen.

It is in his essay 'Fors', which introduces Nicolas Abraham and Maria Torok's The Wolf Man's Magic Word: A Cryptonymy, that Derrida provides an extended articulation of cryptic incorporation. ${ }^{12}$ I shall let the next few paragraphs serve to encapsulate its key features, with occasional commentary on my part.

Cryptic incorporation is for Derrida what mimes or simulates the process of introjection while not effectuating the completion of mourning that introjection accomplishes. While introjection is of the order of presence, re p resentation, the subject, the spirit, the ontological, incorporation is of the order of the simulacrum, the object, the spectre, the hauntological. Its 'in-' is not merely the banal 'in-' of the inside as a fullness of presence of in-trojection but the fatal, radical 'in-' as the irreducibly 'in-' between, the 'in-' between as itself the secret: what would be for Derrida the outside as the inside of the inside or of the outside and the inside as the outside of the outside or of the inside. ${ }^{13}$ With incorporation what is constituted as inner enclave within us remains unassimilated. Derrida writes: 'the walled surfaces of the crypt create an innermost heart of hearts ... which is an excluded outsider inside'. ${ }^{14}$

Incorporation, the simulation of introjection, is nostalgic for what it itself forever staves off: the resolution, reconciliation, closure which introjection aff o rds. Incorporation is of the o rder of the irreconcilable. It operates 'to keep a corpse intact, safe both from life and from death, which could both come in from the outside to touch it'. ${ }^{15}$ For Derrida, 'The inhabitant of a crypt is always a living dead, a dead entity we are perfectly willing to keep alive, but as dead, one we are willing to keep, as long as we keep it, within us, intact in any way save as living'. ${ }^{16}$

The cryptic incorporation thus always marks an effect of impossible or refused mourning. What is kept safe-this Thing-is, like the simulacral nature of the crypt and of cry ptic incorporation, of the order of lifedeath: both dead and alive, neither dead nor alive, at the 
same time. Kept alive as dead and dead as alive, in a word, as the undead, the cryptic object is a foreign body-a stranger-kept within the Self as foreign, expropriated by any attempt to appropriate and synthesise it with the Self. ${ }^{17}$ Which means not only that the work of mourning cannot be completed, but also that the incorporation is never finished.

For Derrida, the crypt is the monument to a catastrophe. According to the strange logic of cryptonymy, any attempt to decrypt the crypt(ic) only serves to encrypt it. In trying to destroy it, it can only be consolidated. ${ }^{18}$ According to its logic, the self becomes a 'lodging, the haunt of a host of ghosts'. ${ }^{19}$ The subject so constituted would be 'particularly resistant to analysis, a subject carrying within him a "puzzle of shards about which we would know nothing: neither how to put it together nor how to recognize most of the pieces"'.20

Finally, let me note this point of Derrida:

The crypt is always an internalization, an inclusion intended as a compromise, but since it is a parasitic inclusion, an inside heterogeneous to the inside of the Self, an outcast in the domain of general introjection within which it violently takes its place, the cryptic safe can only maintain in a state of repetition the mortal conflict it is impotent to resolve. ${ }^{21}$

The strange, irreconcilable, irresolvable topography of the crypt—at once 'inside outside and outside inside', both inside and outside, neither inside nor outside, at the same timeis for me the topography, or rather atopography, the (non)place, of the place of cinema, place of 'the unconscious of the other'. 'As such', the crypt deconstructs the time-honoured distinctions between inside and outside (as in inside and outside the movie theatre), between self and other, subject and object, character and spectator, cinema and world. Even as the crypt of cinema would incorporate the ghost in the host, and vice versa, making it impossible to say which is which, it would incorporate all these other oppositions cryptically. As crypt, the cinema would encrypt in the figure of the spectre what cannot ever be simply decrypted, determined and resolved, even as it would mean that mourning and melancholia would be engaged in an endless exercise to exorcise the ghost, even while maintaining it by that very process.

As spectre, the cinema is never not of the order of the living dead. It always returns from death, lives with death and returns to it, that is, always returns from, lives with and returns to the crypt. Even as spectre and crypt are never not inextricably coimplicated, never not irreconcilably ghosted and cryptically incorporated in the other-the spectre that haunts its crypt, that makes whatever it haunts its crypt, the crypt that always encrypts the spectreso too they together are never not haunting and cryptically incorporating cinema as its very condition of possibility and at the same time impossibility. The life of the spectre in and of the crypt, the life of the spectre in and of the crypt of cinema, is that of lifedeath, at once the life of death and the death of life, life and death inextricably coimplicated, haunted, cry p- 
tically incorporated, making it impossible to determine, reconcile and resolve them-life and death-individually and jointly, even as they cryptically incorporate the world and the spectator-subject, and vice versa.

Here let me pause to enumerate the names of the spectre, so that while I may name but one or two, these others will ghost such a naming. Such names include apparition, doppelgänger, ghost, phantasm, phantasma (the last two notably giving us phantasmagoria), phantom, phasm, poltergeist, revenant, shade, shadow, spirit, spook, sprite, wraith, and more. Their names are legion.

In taking the spectre as 'ur' figure of cinema, with the qualification I made earlier, I take a cue from the fact that the spectre is a privileged subject of film, even giving birth to its 'own' genre-the ghost film - a staple of cinema from its earliest days to the most recent of times. Between 1896 and 1907, a rash of haunted hotel, castle, inn, manoir and chateaux films were made, such as Georges Méliès's L'Hôtel Empoisonné (1896), Le Manoir du Diable (1896), Le Chateau Hanté (1897), L'Auberge Ensorcelée (1897) and Le Revenant (1903); G.A. Smith's The Haunted Castle (1897); Thomas Edison's Uncle Josh in a Spooky Hotel (1900); and J. Stuart Blackton's The Haunted Hotel (1907). More recent examples of this genre include Poltergeist (1982), Evil Dead (1983), Ghostbusters (1984), Beetlejuice (1988), Ghost (1990), Ghost Dad (1990), Truly Madly Deeply (1991), Casper (1995)— to say nothing of the Japanese ghost films such as Ugetsu (1953), Kwaidan (1964), Empire of Passion (1978), Ghost in The Shell (1995). Then there are all those films that acknowledge that special relation between film and the spectre by marking their titles with the sign of the ghost and the haunted house, for example, The Phantom of The Opera.

Moreover, I take a cue from the many comments by perceptive observers of cinema, starting at the very beginning of such comment. Here I wish to return to my opening epigraph from the Russian writer Maxim Gorky: 'Last night I was in the Kingdom of Shadows'. These words open his 4 July 1896 review of his first experience of the Lumière Bros' cinematograph at Aumont's at the Nizhni-Novgorod fair. It stands for me as the first substantial account of the experience of cinema by its spectator-analyst. In his seminal text, 'An Aesthetic of Astonishment: Film and The (In)credulous Spectator', Tom Gunning not only describes Gorky's review as 'the most detailed and articulate account we have of an early Lumière projection', he uses it as the lynchpin for his revision of our understanding of the nature of the earliest form of cinematic spectatorship. ${ }^{22}$ He uses Gorky to argue-against both traditional accounts of the naive spectator and 'certain contemporary theorisations of spectatorship ... [that] envision audiences submitting passively to an all-dominating apparatus, hypnotised and transfixed by its illusionist power'- that the first cinema spectators were quite sophisticated, clued in to the attractions of cinema by their familiarity with the attractions of magic theatre, even as they were inveterate consumers of modern urban life. ${ }^{23}$ If anything, for 
Gunning these spectators tended to a mastery of the experience, maintaining, as Gorky does for him, their recognition of the illusion of the experience while at the same time knowingly immersing themselves in it.

In fact, Gorky appears to define for Gunning, as he does for me, the very experience of cinema spectatorship (and for me too, cinema analysis). Such 'ur' experience persists with Gunning's enduring aesthetic (and therefore cinema) of attractions, which for him provides 'an underground current flowing beneath narrative logic and diegetic realism'-in other words, beneath his cinema of narrative integration-and then re-emergs in the 'SpielbergLucas-Coppola cinema of effects' in the 1970s and 1980s. ${ }^{24}$ The increasing virtualisation of that cinema of (special) effects re p resents for me the ironisation by hyperreal 'cinema' of André Bazin's dream of an integral realism of cinema, even as the attraction produces those moments that for me at once enable and disenable Gunning's cinema of narrative integration and his formulation of it. ${ }^{25}$ Not only does the cinematic attraction produce within the cinema of narrative integration for Gunning 'those moments of cinematic dépaysement beloved by the sunealists', insofar as for him the attraction is never not flowing beneath the cinema of narrative integration, it is never not for me producing by that very flow the dépaysementthe uprooting, rendering homeless (with its association with the uncanny) —of that cinema: the ontological at once enabled and disenabled by the hauntological. ${ }^{26}$

It should be noted that Gunning understands his re fo rmulation of the cinematic spectator in the mould of Gorky as challenging not only the standard take on the earliest spectator but even Christian Metz's 'subtle' reading of the legendary terror of the first audience 'as a displacement of the contemporary viewer's credulity onto a mythical childhood of the medium', onto 'an audience from the infancy of cinema'. ${ }^{27}$ For Gunning, Metz still maintains an attachment to that primal audience, introjecting, projecting and mythicising that legendary first audience, placing the naive credulous spectator inside the incredulous one, or, as Metz puts it, 'still seated beneath the incredulous one, or in his heart' - a critique to which I shall retum. ${ }^{28}$

For me, as it appears for Gunning, Gorky's review is singular for its time in its attempt to characterise the nature and experience of 'moving photography' in the most accurate and ample way possible. Gorky writes of the cinematograph: 'the extraordinary impression it c reates is so unique and complex that I doubt my ability to describe it with all its nuances. However, I shall try to convey its fundamentals. ${ }^{29}$ It is a review marked by a rich, and richly complex, spectrum of idea and affect, so rich and complex in fact that, in conveying 'its fundamentals', it strikes for me all the major notes and chords that more recent commentators will isolate as pertinences not only of the early cinema but also of cinema 'as such'. It is a review so singular for its time and for the fundamentals it conveys of that first experience of cinema that Colin Harding and Simon Popple name their book after it-In The Kingdom 
of Shadows - and situate it at the beginning of their first section of the book, entitled 'The First Sight', leading into it by declaring of this review and the others, 'but what above all characterises these responses to the first sight of the cinema, whether favourable or not, is a sense that something irrevocable has come to pass'. ${ }^{30}$

For me, Gorky's 'first sight' of cinema offers us a rich guide to those qualities of the cinema and its senses whose address is the brief of this essay. It is a guide that not only already apprehends the uniqueness and complexity of cinema but is already shadowed by a doubt about the ability to describe it fully. And more. It is a guide to the experience of the Kingdom of Shadows, and written by someone who has been there and returned from it, who speculates upon cinema and its experience pre-eminently in terms of the spectre, the ghost, the shadow. Let me quote a bit of Gorky in this regard:

Noiselessly, the ashen-grey foliage of the trees sways in the wind, and the grey silhouettes of the people, as though condemned to eternal silence and cruelly punished by being deprived of all the colours of life, glide noiselessly along the grey gro $\mathrm{u} \mathrm{d}$.

Beforeyou a life is surging, a life deprived of words and shorn of the living spectrum of colours-the gre y, the soundless, the bleak and dismal life.

It is terrifying to see, but it is the movement of shadows, only of shadows. Curses and ghosts, the evil spirits that have cast entire cities into eternal sleep, come to mind and you feel as though Merlin's vicious trick is being enacted before you. As though he had bewitched the entire street ...

Three men seated at the table, playing cards ... It seems as if these people have died and their shadows have been condem ned to play cards in silence unto eternity.

The Kingdom of Shadows Gorky characterises is the Kingdom of shades, ghosts, spectres, evil spirits. This Kingdom is for me Hades, the underworld, the land of the spirits of the dead, but of the dead who return to haunt the living as the living dead. This Kingdom, this empire of phantoms, is the Kingdom of Cinema. This Kingdom is ruled by Pluto (called Dis by the Romans) and by Satan. It is a land of the devil, of the evil demon. Its experiencing by Gorky induces in him overpowering affects cogently registered in the following passage:

This mute, grey life finally begins to disturb and distress you. It seems as though it carries a warning, fraught with a vague but sinister meaning that makes your heart grow faint. You a re forgetting where you are. Strange imaginings invade your mind and your consciousness begins to wane and grow $\operatorname{dim} . .$.

But suddenly, alongside of you, a gay chatter and a provoking laughter of a woman is he a rd ... and you remember that you are at Aumont's, Charles Aumont's ... 
The text 'resolves' itself into a set of strongly stated antinomies — pro home and family, the 'clean, toiling life', the Good, the idyll, the bucolic, and anti vice, Evil, family squabbles (what threatens to undo the family, the familiar), the market, fashion. Gorky wonders why such an invention, which 'could probably be applied to the general ends of science, that is, of bettering man's life and the developing of his mind', should be demonstrated at Aumont's, 'where vice alone is being encouraged and popularised'-and his answer is for me already implicit in his question. For Gorky, such an experience of this Kingdom is a deeply shockingfive 'suddenly's mark it—destabilising one, in terms of both sense and sensation. Or should we not 'simply' say sense, to note its undecidable character as idea and feeling, as mental and physical, a term that deconstructs itself. ${ }^{31}$ It is an experience so traumatic in fact that he fears for his body and mind, fears for his life, fears for his grasp of reality, fears for his sanity, fears that the strange reality of cinema is displacing and supplanting his familiar, familial reality, turning himself and his world, I would suggest, not only upside down—as Gunning tends to do to traditional and Marxist film theoretical accounts of cinematic spectatorship via Gorky's account, even as Marxist film theoretical accounts themselves play the simple inversion game-but inside out.

Here let me pause to make a few comments on Gunning's take on Gorky and Metz. Endeavouring to avoid that for which he criticises Metz, Gunning nonetheless, as it were, falls into the same 'traps' in tending to introject, project and mythicise Gorky as primal spectator, one who, in complete opposition to the legendary, totally passive, slave, 'dupe' model of the early film spectator, is a totally active, 'all-knowing', urban sophisticate master - a simple inversion that produces a contradiction in Gunning's characterisation of Gorky as spectator, as it does in Gunning's own role. To wit, Gunning, on the one hand, attempts to forge a 'both/and' model for describing the cinema and its spectator-both believing and incredulous at the same time-modelled on Gorky, while, on the other hand, buying into an either/or binary, assuming the position of master demystifying showman-theoristmodelled also on Gorky-who could simply stand outside the experience, be it as spectator-analyst or as showman-theorist. While Gunning would wish that Gorky support and be his master demystifying showman-theorist-spectator according to the either/or binary, modelling his own operations as theorist thereby, my reading of Gorky begins by situating him at the least on that other side of Gunning's dual reading of him, in the 'both/and' category that Gunning in fact shares with Metz in characterising the early film spectator.

But rather than engage in an extended analysis of the complexities of the arguments over projection and introjection, I wish to add cryptic incorporation to the equation. This addition would deconstruct a simple either/or model of projection and introjection, as it would a simple active-master/passive-slave 'dupe' model of the film spectator-theorist that would simply situate the adult in the former category and the naif, the child and the primi- 
tive in the latter. Indeed, the deconstructive force of cryptic incorporation would go a step fu rther to deconstruct a simple 'both/and' model with its 'both/and, neither/nor, at the same time'-both adult and child, neither simply adult nor simply child, at the same timeacknowledging the impossibility of keeping the opposing terms of the binary, anybinary, separate and discrete, acknowledging their inextricable coimplication, indetermining, reversibility and irreconcilability. And what is thereby acknowledged are the limits of the productivist modelling of cinema and of film theory, the limits of the film theorist's ability to master film, and the superior, uncanny, cryptic powers of the cinema and its seduction of film theory, turning it into a special effect, while keeping the 'secret' of the cinema safe (fors). ${ }^{32}$

As part of his tendency to read and keep Gorky as master of the experience of cinema, the reby in my opinion misreading Gorky, Gunning errs in tending to characterise Gorky's experience as merely one of ennui, of boredom. Even when Gunning expands those terms to include vague discomfort, depression and malaise, he tends to try to confine that range to an intellectual rather than emotional reaction so that Gorky remains totally outside of and immune to cinema's uncanny effects. To the contrary, I believe Gorky offers us not only a complex range of contradictory, irreconcilable senses arising from his immersion in the experience but an account of the unaccountable as the experience of cinema. His 'account' canvasses all the features that would make his experience 'ur' scene and 'ur' sense of cinema-the uncanny experience of cinema - with its simultaneous thrills and chills, delights and frights, attractions and repulsions-indeed, the thrills of the chills, the delights of the frights, the attractions of the repulsions, and vice versa-with its making of the strange (Gorky's 'If you only knew how strange it is to be there') familiar and the familiar strange at the same time, and with its terrifying return of death, returning in the form of the ghost, the spectre-and with it of necessity the return of the experiences of mourning and melancholia and of cryptic incorporation.

I would, therefore, propose that what Gorky describes as his experience of cinema would be the effect of the spectre, the spectre of cinema and its whole set of affects/shocks/ attractions - he Cryptic Complex of the uncanny, the return of death as spectre, endless mourn ing and melancholia and cryptic incorporation. ${ }^{33}$ One might say that the affect of cinema would be the special effect of the spectre. Furthermore, I would argue that, in characterising the complex logics and operations of the experience of cinema with such loaded terms as 'canny' and 'uncanny', Gunning himself supports my reading. In fact, for me all that Gunning says of the advent of the cinema is already in Fre ud's logics of the uncanny. For me, the attraction, film and a fortiori animation are of the order of the uncanny. ${ }^{34}$ Indeed, I propose here they are of the order of the Cryptic Complex, which is 'itself' of the order of the animatic, as a re the elements that compose this complex. 
To nominate the uncanny as 'ur' sense of cinema would have the consequence of resurrecting and 'reaff i rming' the inscription of childhood for which Gunning challenges Metz, for the uncanny has to do with the return of what gave us a fright when we were children to give us a fright again as adults. It suggests that the adult is never only adult but always at the same time child, too, even as it posits two sides to itself - the psychological and the anthropological - two necessarily commingled, cryptically incorporated sides, which means that what returns from one's own childhood is allied with what returns from the childhood of the human:our primitive animistic fears of the return of the dead. And in both the nature of animation is at stake. Such would be the primal experience of cinema, a shocking, traumatic experience that even the sophisticated Gorky rehearses for us. Metz's 'audience from the infancy of cinema' is the audience uncannily returned by cinema to the infancy, the childhood, of the individual and the human. One might say, retumed to children of the night, as Dracula would have it!

Of course, to 'discover' that when you are in the cinema, you are in the Kingdom of Shadows, to 'discover' that when you are in the cinema, your world and you have died and been resurrected as shadow, as spectre, that even as cinema has become the spectre of your world and you, your world and you have become the spectres of cinema, that even as cinema has cryptically incorporated your world and you, your world and you have cryptically incorporated cinema, that there is a stranger, a spectre, encrypted in your world and you such that your world and you are forever strangers to themselves, never able to touch, close upon and secure themselves - this re tu mof death and the indeterminacy and emotions that arrive in its wake would be terrifying. ${ }^{35}$ For me, the traumatic advent of cinema violently opened a wound - a wound in a sense never closed, a posthumous wound-in 'reality', as well as in the 'self', the 'subject', a wound no amount of suturing (and its system) could close. ${ }^{36}$

It is no surprise that at a certain point Gorky reacts against all this 'nonsense', trying to conjure away, to exorcise, to repudiate, the spectre and to reinstate the comforting, reassuring, hierarchical, resolvable either/or: reality or illusion; outside or inside (as in outside the film and its effect or immersed in it); Charles Aumont's or the cinematograph; Good or Evil; master or dupe. ${ }^{37}$ As Gunning reacts against the spectre too. But, for me, Gorky's three ellipsis points three times mark his haunting, even as those points mark the haunting of Baudelaire's poet by the passante, that fugitive apparition of a woman in mourning who at once comes to pass and passes to come of whom Walter Benjamin and Samuel Weber writethe passante, another spectre of cinema. ${ }^{38}$

Gunning is alert to the relevance of the uncanny for his account of Gorky, at least to a degree. He himself declares that Gorky 'stresses the uncanny effect of the new attraction's mix of realistic and non-realistic qualities'; but he constrains his thinking of the uncanny to 
this mix, thereby not taking on board the thinking of Freud on the uncanny for the thinking of Gorky and his experience of cinematic spectatorship. ${ }^{39}$ This thinking is essential to another of Gunning's key points which he grounds in Gorky, as well as in Méliès and Blackton, that is, that the 'ur' attraction/shock/experience of cinema-the experience in and by which it demonstrates its powers to the spectator-is the sudden transformation, the 'magical metamorphosis', from the 'all too familiar' still photographic image to the all too strange mobile cinematographic image of living moving shadows of people and things. Quoting Gorky's famous description of it-'Suddenly a strange flicker passes through the screen and the picture stirs to life'-Gunning sums up this process, what he calls 'this cataclysmic event', as 'this still projection takes on motion, becomes endowed with animation, and it is this unbelievable moving image that so astounds'. ${ }^{40}$

But no more than Fre u d's uncanny does Gunning address the implications of animation for this process, an uncanny, animatic process by which, arguably, the inanimate becomes not merely animate but 'animate inanimate', even as the animate becomes not merely inanimate but likewise 'animate inanimate'. ${ }^{41}$ The 'animate inanimate' would be 'living photography', the term announced on the advertisement outside Aumont's for the wonder p roduced by the Lumiere cinematograph. ${ }^{42}$ This uncanny, animatic process connects the 'living pictures' of cinema to the 'living statues' of classical times, both offering an experience of the return of the dead as living dead, not too alive, not too dead, both alive and dead, neither alive nor dead, at the same time. The return of the dead as spectre, at the least a double ghosting in the case of cinema: the image itself and what it images_living moving shadows of people and things. And a third as well: the strange flicker that passes through the screen! Certainly, Barthes's treatment of the distinction between photograph and film in Camera Lucida would support such a reading, although for me the relation of photograph and cinema would be more complicated, one form of lifedeath ghosting another. Is it not that uncanny sense of the deadreturning to life and at the same time the living returning to death that informs Gorky's response, one Gunning takes as model, a response that repeatedly characterises these living moving forms as shadows, spectres?

So while the process moves from the all too familiar to the all too strange, the all too strange also turns out to be something all too familiar, the things that frightened us when we were children but had thought we had surmounted now that we are adults. Fre ud's characterisation of the uncanny means not simply that the familiar becomes strange but that one is conf ronted with something strangely familiar and familiarly strange at the same time. We are confronted with the return of ghosts, of spectres, whose haunting of ourselves we thought we had surpassed. We feel occupied, in our inside-in our 'innermost heart of hearts' - by what is most strange, distant, threatening. ${ }^{43}$ 
In Specters of Marx, Derrida asks:

Why does Freud consider haunting to be 'perhaps the most striking of all [examples]', 'a kind of prototype, in the experience of Unheimlichkeit? Because many people experience 'in the highest degree' (im allerhochsten Grade) the sense of the 'unheimlich' 'in relation to death and dead bodies, to the return of the dead, and to spirits and ghosts' (Geistern und Gespenstern). ${ }^{44}$

And Derrida highlights Freud's comment: 'Some languages in use to-day can only render the Ge rman expression "anunheimlich house" by "a haunted house". 45

Insofar as for me cinema bears a privileged relation to the uncanny, insofar as cinema's 'ur' sense and experience would be that of the uncanny, cinema too could be thought of its kind 'perhaps the most striking of all [examples]', 'a kind of prototype, in the experience of Unheim lichkeit. The crypt, the haunted house, of cinema would be Freud's 'unheimlich house', and vice versa.

The uncanny nature of the cinema, marked in the event of its advent as described by Gunning, turns the sense of being at home that the spectator felt before the image started to turn from still photograph to mobile cinematograph-the experience of being at an all too familiar spectacle-into a sense of being homeless-unheimlich-with its movement, its tu ming, itsdépaysement, its 'coming to life', its coming-to-pass-its animation. (Here, the expression 'coming to life' needs qualification, a curious locution insofar as I would suggest that life can never be come to, nor death. In any case, it is the illusion of life to which for me this expression alludes-Gorky's 'not life but its shadow ... not motion but its soundless spectre'.) So, too, the relation between film and world becomes homeless, uncanny, as eachfilm and world-invades, cryptically incorporates and indetermines the other. To be in the house (casa) of cinema is not to be in the domus-the home. Its refuge could never be pure refuge, any more than it could be pure non-refuge. Like the spectre, the movie theatre is of the order of the between. To be in it is to be in the haunted house, the crypt, of cinema, chez cinema, ${ }^{46}$ in the 'bio-box' of cinema, in the place of licit illicitness that Metz describes in 'The ImaginarySignifier' ${ }^{47}$ a place akin to a maison de tolérance, which it appears Gorky was next to when he saw the Lumière cinematograph!48

For me, cinema is not only uncanny. The advent of the cinema is an uncanny advent, replayed every time a film is projected-as well as, to not overlook its importance, every time the projection ends, as well as every time an attraction, a 'suddenly', erupts to shock the spectator-the posthumous shock of the uncanny, followed by the posthumous aftershock of mourning and melancholia. In 'The Age of the World as Moving Picture', as I call it, not only does cinema (that is, film animation) double the photograph, it doubles the subject, the self and the world. Even as animation as the animatic doubles all these, making it impos- 
sible to say which is which, producing a double invagination/cryptic incorporation of each in the other-a doubled womb that is at the same time a doubled tomb. ${ }^{49}$

In 'sum', the elements of the Cryptic Complex offer a way of conceptualising film rich in implication, including for the thinking of the sense(s) of cinema and for the rethinking of received theories of cinema, including those of ideology, the imaginary, fetishism, narrative, spectatorship, identification. From this point of view, that of the necrospective, that of the vanishing point of view, every film and every analysis is a tale from, and of, the crypt, making it necessary to rethink cinema, each and every modality of it, through the ghost, the spectre, the Cryptic Complex ${ }^{50}$ — the animatic — to conceive of cinema, of film, as spectro graphy (the writing of the spectre-ghost writing), as cryptography (the writing of the crypt), as thanatography (the writing of death); to conceive of spectatorship, as of analysis, as spectreship, as haunting and being haunted, as encrypting, as mourning and melancholia in perpetuity, no matter what other affects might be generated to cover them over. From this point of view, there is always a spectre and a speculator in the spectator-analyst, always a corpse and a crypt. In fact, the spectres are always in the plural; and they are never laid to rest, never resolved, never reconciled. So too the analysis of the crypt is itself 'the crypt of an analysis'. ${ }^{51}$

Let me close with words from The Rubiyat of Omar Khayam, which for Ian Christie in his book The Last Machine offers a description of human existence in the light of the magic lantern. I wonder, might that lantern have been J.A.R. Rudge's Biophantoscope, which means the view of the life of the ghost, the view of the ghost of life. These words serve as well for our crypt, our haunted house, of cinema:

For in and out, above, about, below,

'tis nothing but a magic shadow-show,

Played in a box whose candle is the sun

Round which we phantom figures come and go. ${ }^{52}$

Send in the ghosts? ${ }^{53}$

Don't bother. They're here.

In this Kingdom of Shadows.

ALAN CHOLOdENKO is former Senior Lecturer in Film and Animation Studies in the Department of Art History and Theory at the University of Sydney, where he now holds the title of Honorary Associate. He is the editor of The Illusion of Life 2: More Essays on Animation, Power Publications, Sydney, forthcoming, 2004. 
1. Colin Harding and Simon Popple, In The Kingdom of Shadows, Cygnus Arts, London, 1996, p. 5. See also Jay Leyda, Kino, Collier Books, New York, 1960 , p. 407, where we find 'Kingdom of Shadows' capitalised.

2. Juan Cobos, Miguel Rubio and Jose Antonio Pruneda, 'Interview with Orson Welles', Cahiers du Cinéma, no. 165, April 1965, reprinted in Cahiers du Cinéma in English, no. 5, 1966, trans. Rose Kaplin, in Inte rviews with Film Directors, ed. Andrew Sarris, Avon Books, New York, 1967, p. 538.

3. Jacques Derrida says this in Ken McMullen's film Ghost Dance (1983).

4. As is the work I would do in this essay, work in keeping with my ongoing project of articulating an uncanny, animatic, Derridean theory of animation, film and cinema-of film and cinema as forms of animation, of all three as forms of the animatic.

5. This essay originally took the form of a paper p resented to the Cinema and the Senses conference, UNSW, November 1998. Readers wishing to pursue other recent scholarship in the area might refer to Adrian Martin, 'Godard's Histoire(s) du Cinéma, Parts 1A \& 1B: Tales from the Crypt', Senses of Cinema, 10, November, 2000, $<$ http://www.filmcritic.com.au>; Laurence Rickels, The Vampire Lectures, University of Minnesota Press, Minneapolis, 1999; William D. Routt, 'Looking Forward and Backward at the Same Time: Maxim Gorky Goes to the Movies', UTS Review, vol. 2, no. 1, May 1996, pp. 72-87; Jeff rey Sconce, Haunted Media: Electronic Presence from Telegraphy to Television, Duke University Press, Durham, 2000.

6. Raymond Bellour, 'The Unattainable Text', Screen, vol. 16, no. 3, Autumn 1975, and Raymond Bellour, 'Analysis in Flames', Diacritics, Spring 1985.

7. Jacques Derrida, Specters of Marx, trans. Peggy Kamuf, Routledge, New York, 1994, p. 161.

8. Derrida, Specters of Marx, p. 161.

9. De rrida, Specters of Marx, p. 120.

10. This figure would mark a crucial 'conjunction' of what is privileged in cinema and what is privileged in Derrida. He declares: 'the logic of spectrality ... inseparable from the very motif ... of deconstruction, is at work, most often explicitly, in all the essays published over the last 20 years'. Derrida, Specters of Marx, p. 178, note 3.

11. Derrida, Specters of Marx, p. 126.

12. Jacques Derrida, 'Fors', in Nicolas Abraham and Maria To rok, The Wolf Man's Magic Word: A Cryptonymy, trans. Nicholas Rand, University of Minnesota Press, Minneapolis, 1986.
13. Abraham and Torok, p. xix.

14. Abraham and Torok, 'Translator's Introduction', p. lxviii.

15. De rrida, 'Fors', p. xxi.

16. Derrida, 'Fors', p. xxi.

17. Derrida, 'Fors', p. xvii

18. Derrida, 'Fors', p. xxii.

19. De rida, 'Fors', p. xxiii

20. Derrida, 'Fors', p. xx.

21. De rrida, 'Fors', p. xvi.

22. Tom Gunning, 'An Aesthetic of Astonishment: Film and The (In)credulous Spectator', Art and Text, 34, Spring 1989, p. 34.

23. Gunning, p. 32.

24. Gunning, p. 38; Tom Gunning, 'The Cinema of Attraction: Early Film, Its Spectator and the Avant-Garde', Wide Angle, vol. 8, no. 3/4, 1986, p. 70 .

25. A process which I take up in my essay "OBJECTS IN MIRROR ARE CLOSER THAN THEY APPEAR": The Virtual Reality of Jurassic Park and Jean Baudrillard', in Nicholas Zurbrugg (ed.), Jean Baudrillard, Art and Artefact, Sage Publications, London, 1997.

26. Gunning, 'An Aesthetic of Astonishment', p. 38.

27. Gunning, 'An Aesthetic of Astonishment', p. 32.

28. Christian Metz, 'The Imaginary Signifier', Screen, vol. 16, no. 2, Summer 1975, p. 70.

29. Ha rding and Popple, p. 5.

30. Ha rding and Popple, p. 3.

31. Not only does Gunning ground cinema in the shock delivered from cinema's inception by what he calls pertinently the cinema of attractions, so too do many commentators, including Walter Benjamin, who declares: 'There came a day when a new and urgent need for stimuli was met by the film. In a film, perception in the form of shocks was established as a formal principle'. 'On Some Motifs in Baudelaire', Illuminations, trans. Harry Zohn, Fontana Press, London, 1992, p. 171.

32. On this issue of mastery, see Cholodenko, “"OBJECTS IN MIRROR”, p. 82, note 19. Insofar as Gunning's reading — and Metz's too-is 'both/and', it can be seen to be on the road to the 'both/and, neither/nor, at the same time'. I would wish my words 'attempts to' in note 19-that Gunning on the one hand 'attempts to' forge a sophisticated 'both/and, neither/nor' model ...to be soread.

33. After presenting this paper at the Cinema and the Senses conference, I had occasion to read Laurence A. Rickels' Aberrations of Mouming: Writing on German Crypts, Wayne State University Press, Detroit, 1988. His work is a clear precedent for this essay, which, at the least, arguably seeks to systematise and clarify, as well as to extend, including via Derrida's Specters of Marx, some of 
Rickels's gro und breaking insights in terms of film and, unlike Rickels, to engage in a dire ct elaboration of a theory of film 'as such'-as animation.

34. That cinema bears a special relation to the uncanny is a point I made and subject I addressed in the Introduction to Alan Cholodenko (ed.), The Illusion of Life: Essays on Animation, Power Publications in association with the Australian Film Commission, Sydney, 1991.

35. In this sense, J. Stuart Blackton's description of watching the frozen train 'take life' harbours a paradoxical, threatening implication not only for that train but also for the train of cinema itself.

36. For Derrida, mourning always follows a trauma. Specters of Marx, p. 97.

37. The shock of the experience is registered even in Gorky's repeating the name Aumont and in doing so the second time by putting Charles in front of the surname to emphasise his re tu rn to familiar, comforting, reassuring territory.

38. See Walter Benjamin, 'The Paris of The Second Empire in Baudelaire', Charles Baudelaire: A Lyric Poet in the Era of High Capitalism, trans. Harry Zohn, Verso, London, 1976, 1985, p. 45, where Zohn's translation uses the term 'apparition' to describe the passante; and Benjamin, 'On Some Motifs in Baudelaire'. As well, see Samuel Weber, 'Mass Mediauras, or: Art, Aura and Media in the Work of Walter Benjamin', in Alan Cholodenko (ed.), Mass Mediauras: Form, Technics, Media, Power Publications/Stanford University Press, Sydney/Stanford,1996, pp. 94-8, where Weber too speaks of the ghostly apparition of the passante.

39. Gunning, 'An Aesthetic of Astonishment', p. 34

40. Gunning, 'An Aesthetic of Astonishment', pp. 34,35 .

41. See my introduction to The Illusion of Life, p. 29

42. The information about the ad is in Leyda, Kino, p. 20.

43. Derrida, Specters of Marx, p. 145. Here we might compare Metz's 'heart' with Derrida's 'innermost heart of hearts' to cleave a space between p rojection and introjection, on the one handif that is what Metz is doing-and cryptic incorporation, on the other.

44. Derrida, Specters of Marx, p. 195, note 38.

45. Derrida, Specters of Marx, p. 195, note 38.

46. In 'Reading and Writing — chez Derrida', in Institution and Interpretation,University of Minnesota Press, Minneapolis, 1987, Samuel Weber connects chez with case, casa, casino, cassette, a point I reference in "OBJECTS IN MIRROR", where I add to that list two key terms not mentioned by Weber-casket and coffin.

47. Metz, p. 65.

48. Ian Christie writes: 'a modern Russian historian has pointed out that Gorky saw the Lumière cinematograph in a fairg round next door to what was believed to be a brothel'. The Last Machine: Early Cinema and the Birth of The Modern World, BBC Education, London, 1994, p. 15.

49. Double invagination and cryptic incorporation take their place among a long list of such 'undecidable', aporetic terms in Derrida, nonidentical, nonequivalent terms which substitute for, supplement, each other in a potentially infinite chain of such terms and which serve to mark the unaccounted for operations of the repressed but irrepressible trace, mark of the other.

50. In terms of this rethinking, I would single out William Rothman's chapter on Psycho in his exceptional text Hitchcock: The Murderous Gaze, Harv a rdUniversity Press, Cambridge, 1982. It is a p recedent for this paper.

51. Derrida, 'Fors', p. xxiv.

52. I would say 'Played in a "bio-box"/haunted house/crypt whose candle is the moon', that is, the doubled sun, that of Thoth, Isis, Iris - that of the illusion of life. See my 'Who Framed Roger Rabbit, or The Framing of Animation', in The Illusion of Life, pp. 231-2.

53. See Adrian Martin, 'Send in the Ghosts', in Phantasms, McPhee Gribble Publishers, Melbourne, Australia, 1994. 